\title{
TOURISM DEVELOPMENT CONDITIONS IN THE MUNICIPALITIES OF LITHUANIA AND LATVIA REGIONS
}

\author{
Ramutė Narkūnienė, ${ }^{1}$ Vladimiras Gražulis, ${ }^{2}$ Iluta Arbidane ${ }^{3}$
}

\begin{abstract}
The authors of this article discuss the tourism development conditions in the municipalities of the Eastern Aukštaitija region, in Lithuania, and the Latgale region, in Latvia. The aim of the research is to explore tourism development conditions in the municipalities of the Eastern Aukštaitija region, in Lithuania and Latgale region, in Latvia. Objectives of the research are to characterize the factors influencing the development of tourism, to perform an analysis of the main factors of tourism development of the Eastern Aukštaitija region in Lithuania and the Latgale region in Latvia, and to define the major factors of tourism management in the municipalities of the Eastern Aukštaitija region, and the Latgale region. The scientific problem - the tourism development trends have not been studied in a local, municipality level in Lithuania and Latvia and tourism in districts is developed without a clear and long-term development strategy and consistent implementation of the program. The authors of the article apply the analysis of scientific literature, quantitative research - a survey and questionnaire data generalization. Six tourism specialists in the eastern Aukštaitija region, and 30 tourism specialists in the Latgale region, were interviewed. Tourism development issues are discussed and the results of the research (analysis of scientific literature and the questionnaire, analysis of strategic documents) are performed. The conclusions of article are: factors which influence tourism in the Lithuanian and Latvian regions most are the image of tourism destination/awareness, quality of tourism services, management of tourism destination, variety of tourism services and tourism infrastructure. Second conclusion: tourism specialists identified management of tourism destination, image of tourism destination/ awareness, quality of tourism services in Lithuania region; cultural, natural and human resources and tourism services (travel organization, tourism information services, nutrition in the Latvian region, as tourism development strengths in municipalities of the Lithuanian and Latvian region; tourism diversity and tourist infrastructure in the Lithuanian region and tourism infrastructure and entertainments in Latvia region were identified as weaknesses. Third conclusion: tourism development in both regions is threatened by such factors as unplanned changes of the state economic development priorities, population migration to other countries and other factors. While, tourism development in the region can benefit from EU funds, and the growing demand for active recreation and health tourism products in the hospitality industry and etc. Tourism development at the municipalities of both regions in Lithuania and Latvia is influenced by such factors, as the development of the tourism planning and management system, adequate competence of human resources, cooperation between public and private sectors, planning and organization, legal tourism base, tourism projects development and implementation, tourism development strategy and research in the tourism development area.
\end{abstract}

JEL classification number: Z32; DOI: http://dx.doi.org/10.12955/cbup.v5.945

UDC classification: 35

Keywords: tourism, tourism development, factors, conditions, region, municipality, Lithuania, Latvia.

\section{Introduction}

Due to the influence of economic, social and political globalization processes tourism has become one of the leading industries in many countries. According to the data from the World Tourism Organisation (WTO), tourism, which has a direct and indirect impact on economics, on a global scale creates $9 \%$ GDP, 1 in 11 jobs, 6\% of the world's exports, and forecasts an increase of international tourists up to 1.8 billion for 2030. Over the last decade, tourism has become an important economic sector in Lithuania and Latvia - since 2009 each year inbound tourism revenue steadily increases. Many scientists have analysed tendencies of tourism development: Dwyer and Kim (2003), Gunn (2002), Dmitrijeva and Šniavskij (2009) analysed tourism destination competitiveness factors, Dredge and Jenkins (2007), Sharpley and Telfer (2002), Hall (2007) - analysed tourism planning and development, and Go and Govers (2000) - analysed integrated quality management for tourism destination and others. In Lithuania, these issues were analysed: trends and development of modern tourism (Korneičiuk and Pipirienè 2015), assessment of the Lithuanian tourism potential (Andrulienè et al, 2011), conceptualization and trends of tourism development in Lithuania (Žilinskas and Petravičiené, 2007), tourism development and management (Ligeikiené, 2003), management of tourism development in the regions (Žilinskas and Skrodenienè, 2003) and others. Tendencies of tourism development at the municipality level were researched by Paulauskienè (2013), who analyzed perspectives of tourism management development in Lithuania and Dapkus and Gaižauskienè (2009)

\footnotetext{
${ }^{1}$ Mykolas Romeris University, Faculty of politics and management, / Professor, Utena College, Lithuania, ramutenarkuniene@gmail.com

${ }^{2}$ Professor, Mykolas Romeris University, Faculty of politics and management, , Lithuania, gra.vlad@gmail.com

${ }^{3}$ Professor, Rezekne Academy of Technologies, Economics and Management Faculty, Latvia, iluta.arbidane@inbox.lv
} 
reviewed tourism development at the municipality level. However, tourism development conditions at the municipality level have not been researched, only sporadic studies have been performed. For these reasons, tourism in many municipalities has developed without a clear and long-term development strategy and consistent implementation of the program.

The object of the research is tourism development conditions in the municipalities of Eastern Aukštaitija region, Lithuania and Latgale region, Latvia.

The aim of this research is to explore tourism development conditions in the municipalities of the Eastern Aukštaitija region in Lithuania, and the Latgale region in Latvia.

Objectives of the research are

- To characterize the factors influencing the development of tourism.

- To perform the analysis of the main factors of tourism development of the Eastern Aukštaitija region in Lithuania and the Latgale region in Latvia.

- To define the major factors of tourism management in municipalities of the Eastern Aukštaitija region and Latgale region.

Research methods. The authors of the article apply the analysis of scientific literature, quantitative research - as well as a survey and questionnaire data generalization. The research instrument (questionnaire) was developed by grouping questions into blocks related to the research topic for the qualitative and qualitative studies. Six tourism specialists, responsible for the tourism development in the Eastern Aukštaitija region (Anykščiai and Utena municipalities and specialists of Utena, Ignalina and Zarasai tourism information centres, Molètai tourism and business information centre) in Lithuania and 30 tourism specialists in the Latgale region; in the municipalities of Daugavpils city, Daugavpils district, Rēzekne city, Rēzekne district, Aglona, Baltinava, Balvi, Cibla, Dagda, Ilūkste, Kārsava, Krāslava, Līvāni, Ludza, Preiḷi, Riebiṇi, Rugāji, Vārkava, Viḷaka, Viḷāni and Zilupe districts, were interviewed.

Tourism development issues are discussed and the research results are presented.

\section{Literature review}

The WTO defines tourism as a type of travel, tour, when a person leaves his job and place of residence for more than one day and less than 12 months, and the aim of the trip is not recruitment or paid activities (www.unwto.org). For all countries, welcoming tourists is one of the most important conditions to preserve and develop their national identity. Tourism development is understanding the physical changes caused by increasing tourist interest in the area and this expression of interest in performance - increasing incoming traffic According to Ligeikienè (2003) tourism development can be seen as an assumption for the improvement of life quality of tourists and the local community. Tourism development goals in the overall economic structure have impact on and relate to strategies of other branches of the economy, their actions and measures, and the public sector, such as environmental protection, transport, agriculture, regions, development of small and medium businesses. Tourism and regional development are linked to each other in the national and even global context (WTO, 1980). Sharpley and Telfer (2002) state that tourism has a direct impact on national, regional and local economics, whereas tourism development has potentially beneficial economic effects, which in turn positively affects the destination's economic development. Hall (2007) has stated that tourism development has a new tradition of sustainable development, formed in the last decades.

In many countries, the most popular tourist attractions are related with natural resources (the sea, beaches, climate, mountains, and so on). This shows that the development of tourism (as well as economic benefits) is based on the natural resources that are free, because they do not need to be built or created (Dredge and Jenkins, 2007). In order to determine the development of tourism destination, tourism resources of the destination have to be estimated.

Tourism attraction affects service development, which is composed of tourism resources (natural, cultural, social/human) and infrastructure; tourism industry components (accommodation, meals, transportation, entertainment, information, management, travel organization, training services); status of tourism destination (for example, a resort, a UNESCO world heritage site, etc.); image of tourism destination; activities of tourism interested agents; and location of tourism destination in the tourism 
network (Andrulienè et al, 2012). Table 1 summarizes various factors which influence tourism destination development.

\begin{tabular}{|l|l|}
\hline \multicolumn{2}{|l|}{ Table 1: Factors, which influence the development of a tourism destination } \\
\hline Author & Factors \\
\hline $\begin{array}{l}\text { Indriūnas } \\
(2015)\end{array}$ & $\begin{array}{l}\text { Leisure (recreation) objects, infrastructure of services, infrastructure of } \\
\text { passenger transport, engineering infrastructure of the tourism destination, } \\
\text { organization of travel, tourism information and advertising }\end{array}$ \\
\hline $\begin{array}{l}\text { Andruliene et } \\
\text { al }\end{array}$ & $\begin{array}{l}\text { Tourism resources and infrastructure, components of tourism industry, the flow } \\
\text { of tourists, the image of the tourism destination, activities of tourism interested }\end{array}$ \\
agents, the position of tourism destination in the tourism network.
\end{tabular}

As we can see, experts recommend assigning tourism resources, tourism infrastructure, variety of tourism services, tourism management, virtual environment, the quality of tourism services, the image of tourism destination, and the events to the development factors of a tourism destination.

Sharpley and Telfer (2002) note, that the contractual basis of operation of the private and public sectors of the economy, makes it possible to form a common approach to national, regional and local development goals and allows the necessary conditions to evaluate tourism by using a wide range of indicators, such as job creation, economic diversification, support for public services in the development of recreational services for tourists and etc.

In practice, the development of tourism is realized through plans and selected indicators. Gunn (2002) was one of the first scholars to describe tourism planning as a tourism destination development tool. According to Gunn (2002), the aim of planning is related with the increase of income and employment, conservation of resources and conditions for traveler satisfaction. It is noted that in insufficiently or under-developed tourism destinations, plans can become a serious support for further development of tourism, while in the developed countries (regions) they are often used as a tool to 'revive the tourism sector and to maintain its viability in the future' (WTO, 1994). 


\section{Results and Discussion}

\begin{tabular}{|l|l|l|}
\hline \multicolumn{3}{|l|}{ Table 2: Assessment of important factors, affecting Lithuanian and Latvian tourism development } \\
\hline Factors & $\begin{array}{l}\text { Assessment (5-point system) in } \\
\text { Lithuania region }\end{array}$ & $\begin{array}{l}\text { Assessment (5-points } \\
\text { system in Latvia } \\
\text { region) }\end{array}$ \\
\hline $\begin{array}{l}\text { Tourism resources (cultural, } \\
\text { natural, human, financial) }\end{array}$ & 4.80 & 4.00 \\
\hline Tourism infrastructure & 4.20 & 4.10 \\
\hline Tourism services & 4.00 & 4.00 \\
\hline Virtual environment & 4.80 & 4.30 \\
\hline $\begin{array}{l}\text { Image of tourism destination/ } \\
\text { awareness }\end{array}$ & 5.00 & 5.00 \\
\hline $\begin{array}{l}\text { Management of tourism } \\
\text { destination }\end{array}$ & 5.00 & 4.90 \\
\hline Quality of tourism services & 5.00 & 5.00 \\
\hline Events & 4.10 & 3.50 \\
\hline Source: Authors & & \\
\hline
\end{tabular}

As we can see, tourism specialists from both regions rated the same factors with similar points, such as image of tourism destination/awareness (5.00 points), quality of tourism services (5.00 points), management of tourism destination (Lithuania tourism specialists are evaluated as 5.00 points, Latvian tourism specialists -4.90 points), tourism services (4.00 points), tourism infrastructure (Lithuania tourism specialists are evaluated as 4.20 points, Latvian tourism specialists -4.10 points). Tourism specialists in the Eastern Aukštaitija region, rated image of tourism destination, virtual environment and resources quite high (see Table 2). Improvement of the image of the tourism destination and the popularization of tourism opportunities contribute to local social and economic issues and welfare. Evaluating the resources, the maximum score was given to the human and financial resources, a slightly lower grade was given to the natural and cultural resources (cultural resources are evaluated as 4.60 points, natural -4.50 points, human and financial resources are evaluated 5.00 points each). Human resources in the tourism sector are very important, because employees of this sector create the country's tourism and hospitality image and hospitality is an integral part of the competitiveness of tourism sector. In order to strengthen this potential, it is important to continuously develop professional competence of the tourism sector employees, i.e. to constantly improve their skills, knowledge of foreign languages, to improve the image, and develop intercultural competence. A country's tourism resources are one of the most important competitive advantages to attract tourist flows and increase the economic benefits of tourism. Abundance and diversity of Lithuanian and Latvian natural and cultural tourism resources allows to create and develop products of recreation, cultural and educational tourism, ethnic, rural tourism and eco-tourism, focusing on the segments of respective market. Tourism specialists in the Latgale region rated quality of tourism services and image of tourism destination/ awareness quite high (see Table 2). Evaluating the resources, the maximum score was given to human resources, financial and natural resources (human resources are evaluated as 5.00 points, financial resources are evaluated as 4.90 points, natural resources are evaluated as 4.50 points. Cultural resources are evaluated as 4.00 points). Evaluating the cultural resources, for tourism specialists from the Lithuanian region, the highest score (5.00 points) was evaluated to homesteads and museums, folk crafts were evaluated as 4.70 points, urban heritage and folk traditions -4.30 points each, and arts and archaeological assets -4.00 points each.

For tourism specialists from Latvia evaluating cultural resources, the highest score (4.70 points) was evaluated to urban heritage, folk traditions (4.70 points) and folk handicrafts (4.60 points). Evaluating the tourism infrastructure, tourism specialists from the Lithuania region the highest score (4.80 points) were evaluated to asphalted roads, camping (4.60 points) car parking (4.60 points) and bicycle tracks (4.40 points). Evaluating the tourism infrastructure, tourism specialists from Latvia region the highest 
score (5.00 points) were evaluated to asphalted roads, car parking (4.90 points) and camping (4.20 points).

Tourism specialists, while evaluating management peculiarities in the tourism area in their municipalities, noted the development of the tourism planning and management system, adequate competence of human resources, cooperation between public and private sectors, planning and organization, legal tourism base, tourism projects development and implementation, tourism development strategy and researchers in the tourism development area.

According to the results of research, the following tourism types are developed in the Eastern Aukštaitija region of Lithuania: cultural sightseeing, leisure, recreation, rural, health tourism and ecotourism; leisure, recreation, rural, niche and adventure tourism are developed in the Latgale region of Latvia. The Eastern Aukštaitija region's rich natural resources create preconditions for the development of all the above mentioned kinds of tourism, and the development of health tourism related to the activities of resort areas of the region. There is a variety of tourism services in the Eastern Aukštaitija region, and Latgale region.

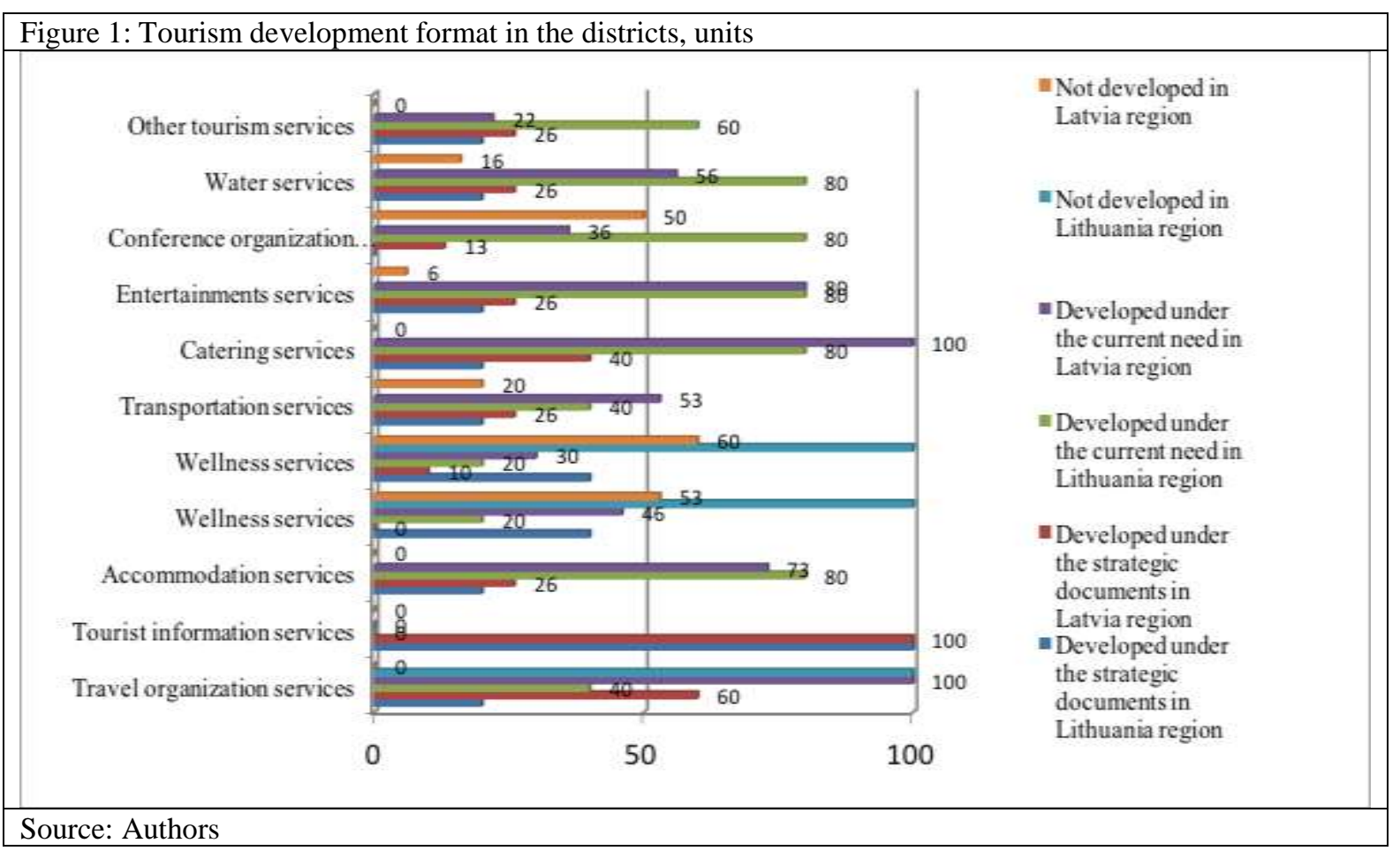

Tourism services are developed according to the current need (conference organization, catering, water, entertainment, transportation and so on) or in accordance with the strategic documents (tourism information, travel organization, health, wellness and other services) in the Lithuania region; tourism services are developed according to the current need (catering, entertainment, accommodation, water services, transportation and so on) or in accordance with the strategic documents (tourism information services, tourism services, catering and other services) the in Latgale region, Latvia (see Figure 1). Tourism specialists identified management of tourism destination, quality of tourism services, image of tourism destination/awareness, the impact of virtual environment on the development of tourism, human and financial resources as tourism development strengths in the Eastern Aukštaitija region. Cultural, natural and human resources and tourism services (travel organization, tourism information

services, catering were identified in the Latgale region as tourism development strengths. Tourism specialists identified tourism diversity and tourist infrastructure (no bicycle path network, the lack of car parking spaces and hiking trails, poor quality of district roads, inadequate infrastructure of water ways) in the Lithuania region and tourism infrastructure and entertainment in the Latvia region, as weaknesses. There are such threats for tourism development in the Lithuanian and Latvian regions as unplanned change of state economic development priorities, population migration to other countries, the worsening demographic situation in the district and others. Tourism development in the Lithuanian and Latvian regions can benefit from EU funds, the growing demand for active recreation and health 
tourism products in the hospitality industry, quality improvement and implementation of international standards and other options in domestic and foreign markets.

\section{Conclusions}

1. Factors which influence tourism in the Lithuanian and Latvian regions most are the image of tourism destination/awareness, quality of tourism services, management of tourism destination, variety of tourism services and tourism infrastructure.

2. Tourism specialists identified the management of tourism destination, image of tourism destination/ awareness, quality of tourism services in Lithuanian region, while cultural, natural and human resources and tourism services (travel organization, tourism information services, catering services) were identified in Latvian region. Tourism development strengths were tourism diversity and tourist infrastructure in the Lithuanian region and tourism infrastructure and entertainments in the Latvia region were identified as weaknesses. Tourism development in the both regions is threatened by such factors as unplanned change of state economic development priorities, population migration to other countries and others, tourism development in the region can benefit from EU funds, the growing demand for active recreation and health tourism products in the hospitality industry and etc.

3. Tourism development at the municipalities of both regions in Lithuania and Latvia is influenced by such factors, as the development of the tourism planning and management system, adequate competence of human resources, cooperation between public and private sectors, planning and organization, legal tourism base, tourism projects development and implementation, tourism development strategy and research in the tourism development area.

\section{References}

Andrulienè, R., Armaitienè, A., Povilanskas, R., Janulienė, R., Dulskis, D. (2011). Lietuvos turizmo potencialo ịvertinimo, nustatant didžiausias turistinès traukos vietoves ir jų panaudojimo prioritetus, studija. Vilnius. Internet access: www.tourism.lt/.../Turizmo_potencialo_ivertinimo_studija_2012.doc

Dapkus, R., Gaižauskienè, E. (2009). Turizmo plètros perspektyvos vietos savivaldos lygmeniu. Ekonomika ir vadyba: aktualijos ir perspektyvos. 3 (16). 60-72. ISSN 1648-9098.

Dmitrijeva T. E., Šeniavskij V. A. (2009). Региональная экономика, тема номера: Туризм. УДК [Regional economy,theme of the issue: Tourism. UDC] 338.467.6:338.48(470.13)

Dredge, D., Jenkins, J. (2007). Tourism planning and policy. Brisbane: Wiley.

Dwyer, L., Kim, C. (2003). Destination competitiveness: determinants and indicators. Current Issues in Tourism. 6 (5): 369 414.

Go, F., Govers, R. (2000). Integrated quality management for tourism destination: a Europen perspective on achieving competitiveness. Tourism management 21, (1), 79-88.

Gunn A. C. (2002). Tourism planning. Fourth edition. New York: Taylor and Francis Books, Inc.

Hall, C. M. (2007). Tourism and regional competitive ness. Advances in Tourism Research, p. 217-230.

Indriūnas, G. (2015). Turizmo planavimas (nota bene). 285 p.

Korneičiuk, J., Pipirienè. (2015) V. Šiuolaikinio turizmo tendencijos ir plètra. 18-osios Lietuvos jaunųų mokslininkų konferencijos „Mokslas - Lietuvos ateitis“ teminè konferencija „Verslas XXI amžiuje“. eISSN 2029-7149.

Ligeikienè, R. (2003). Turizmo plètra ir valdymas (Daktaro disertacija, Kauno technologijos universitetas).

Pasaulio turizmo organizacija [World tourism organization]. Internet access: www.unwto.org.

Paulauskienė, L. (2013). Turizmo valdymo tobulinimo perspektyvos Lietuvoje: nacionalinio ir savivaldybių lygmenų sąveika (Daktaro disertacija, Mykolo Romerio universitetas.)

Sharpley, R., Telfer, D. J. (2002) Tourism development. Concepts and issues. Cambrian printers Ltd.

Wöber, K. W. (2002). Benchmarking in Tourism and Hospitality Industries: the Selection of Benchmarking Partners.

Žilinskas, V. J., Petravičienè, L. (2007). Turizmo verslas: plettros konceptualizacija ir tendencijos Lietuvoje. Ekonomika ir vadyba, 12. Tarptautinès mokslinès konferencijos pranešimų medžiaga. -Kaunas, Technologija.

Žilinskas, V. J., Skrodenienè, A. (2008). Turizmo plètros valdymas regione. Internet access: http://mts.asu.lt/mtsrbid/article/viewFile/595/621 